\title{
A Metaphor: Religious Beliefs Exist Because Yawning Is Contagious
}

\author{
Olivier Walusinski \\ Private Practice, Brou, France
}

'God is the only being who, to reign, does not need to exist'. Charles Baudelaire, Fusées, 1867.

\section{Dear Sir}

Can a physiological behavior explain a cultural phenomenon ('to believe is an inherent feature of human thinking' [1])? Can a cognitive process be supported by innate neuronal circuits dedicated to a homeostatic function (yawning [2])? To contribute to the cognitive science of religion, still under construction, we suggest that the neuropsychological mechanisms underlying contagious yawning can help to elucidate, at least in part, the cognitive processes involved in religious beliefs.

Gods and supernatural beings, the concepts underlying religion, are represented and processed by the human mind as social agents, as members of the human social network [3]. Neuroimaging studies indicate that thinking about or praying to a god activates brain networks known to be implicated in mentalizing. Mentalizing is associated with a tendency to personify gods, and the same mentalizing biases that are typically found when reasoning about other peoples' minds are also found when inferences are made about a god's mind [4]. These capacities to attribute a mental state to others and to build knowledge of mental states in oneself define the concept of 'theory of mind' (TOM). One consequence of this is that humans can also empathize with others, that is, share their feelings and emotions in the absence of any direct emotional stimulation to themselves [5]. Contagious yawning, the onset of a yawn triggered by seeing, hearing, reading, or thinking about another person yawning, occurs as a conse- quence of the ability to infer or empathize with what others want, know, or intend to do, requiring the neurological substrate responsible for self-awareness and empathic modeling, by which a corresponding response is produced in oneself [6].

In this way, gods are seen by some as plausibly real because thoughts about them activate systems involved in TOM and social exchange. As we have seen, TOM systems are the underlying neural mechanisms that the brain relies on to trigger contagious yawning. Religious beliefs activate the same neural and cognitive systems that guide social interaction with other humans. Therefore, without the contagiousness of yawning, the belief in god would be impossible.

\section{References}

1 Bogousslavsky J, Inglin M: Beliefs and the brain. Eur Neurol 2007;58:129-132.

$>2$ Walusinski O: The Mystery of Yawning in Physiology and Disease. Basel, Karger, 2010.

-3 Boyer P: Religious thought and behaviour as by-products of brain function. Trends Cogn Sci 2003;7:119-124.
Tremlin T: Minds and Gods, The Cognitive Foundations of Religion. New York, Oxford University Press, 2006.

5 Adolphs R: The social brain: neural basis of social knowledge. Annu Rev Psychol 2009;60: 693-716.
Platek SM, Critton SR, Myers TE, Gallup GG: Contagious yawning: the role of self-awareness and mental state attribution. Brain Res Cogn Brain Res 2003;17:223-227.
Olivier Walusinski

Family Physician, 20 rue de Chartres 28160 Brou (France)

E-Mail walusinski@baillement.com 